\title{
SAWAHLUNTO DAN PELESTARIAN MULTIKULTURAL: SEBUAH SUMBANGSIH PEMIKIRAN UNTUK WISATA TAMBANG BERBUDAYA
}

\author{
SAWAHLUNTO AND MULTICULTURAL CONSULTATION: A \\ RESOLUTION OF THOUGHTS TO CULTURAL MINE TOURISM
}

\author{
Zusneli Zubir \\ Balai Pelestarian Nilai Budaya Sumatera Barat \\ Jl. Raya Belimbing No. 16 A, Kuranji, Padang \\ zusneli_z@yahoo.co.id
}

\begin{abstract}
Abstrak
Sawahlunto- kota yang terbentuk dari aktivitas tambang batubara memang pernah jaya pada masanya. Lebih kurang seabad lebih lamanya, perusahaan tertua di Pulau Sumatera itu pernah hidup dan menghidupi Kota Sawahlunto dan Sumatra Barat pada umumnya. Untuk mengembangkan tulisan ini, lebih lanjut ada dua pertanyaan yang bisa diajukan, yakni apa sebab-sebab Sawahlunto beralih menjadi kota tambang wisata berbudaya?, dan bagaimana pengembangan wisata Sawahlunto dari sisi analisis SWOT?. Pasca tahun 2002, Sawahlunto sudah memasuki masa purna tambang. Seluruh kegiatan tambang terbuka sudah tidak memadai, dan pendapatan APBD Kota Sawahlunto pun turut berpengaruh karena selama ini bergantung pada masukan dari PT. Bukit Asam (Persero), Tbk-Unit Pertambangan Ombilin (PT.BA-UPO). Pemerintah Sawahlunto, dibawah Walikota Amran Nur, berupaya keras untuk mendatangkan devisa bagi kota tambang. Jadilah konsep dari kota tambang menjadi kota wisata tambang berbudaya. Mengingat pemasukan wisata tambang ini bisa menjadi andalan Sawahlunto kedepannya, ada beberapa hal yang perlu dicermati terutama berkenaan dengan analisis SWOT. Bila empat hal dalam analisis SWOT itu bisa ditanggulangi, Pemko Sawahlunto akan mudah menjadikan daerahnya sebagai destinasi wisata.
\end{abstract}

Kata Kunci: Sawahlunto, wisata, tambang, budaya.

\begin{abstract}
Sawahlunto is a city which formed from coal mining activity was ever victorious in its time. More or less a century more, the oldest company in Sumatera Island was ever lived and sustain the Sawahlunto city and West Sumatra in generaly. To developing this paper, there are two questions that can be asked, what the cause so Sawahluto turned into a cultural tourism with mining city? and how to development tourism of Sawahlunto in side analysis of SWOT?After the year 2002, Sawahlunto has entered the purna tambang. All open mining activities are inadequate, and the revenue of Kota Sawahlunto's APBD also has an effect because it depends on input from PT. Bukit Asam (Persero), Tbk-Mining Unit Ombilin (PT.BA-UPO). The government of Sawahlunto, under Mayor Amran Nur, strives to bring in foreign exchange for mining cities. The concept of a mining town into a cultured mining town was created, it will given income of this mining tour can be a mainstay of Sawahlunto in the future, there are some things that need to be observed, especially with regard to SWOT analysis. Iffour things in the SWOT analysis that can be overcome, Pemko Sawahlunto will easily make the area as a tourist destination.
\end{abstract}


Keywords: Sawahlunto, tourism, mining, culture.

\section{PENDAHULUAN}

Sawahlunto hari ini (2017) sudah berumur 129 tahun. Sebuah usia yang tua untuk sebuah kota tambang di Pulau Sumatra. Sejak beroperasi tahun 1892, Ombilin Mijnen telah menggairahkan perekonomian Sumatra Westkust, terutama pada akhir abad ke-19. Hadirnya Ombilin Mijnen menyebabkan munculnya dua perusahaan transportasi massa yang sampai kini masih bertahan di Sumatera Barat. Sebut saja pelabuhan Emmahaven (1891) dan rel kereta api yang dibangun secara bertahap sampai tahun 1893 oleh N.V. Nederlands-Indische Spoorweg Maatschappij (Verslag der Exploitatie dan Abrar: 2001)

Pada tahun 1910 sebagai kelanjutan dari eksplorasi tambang di Sumatera Westkust, melalui NV Nederlandsch Indische Portland Cement Maatschappij (NV NIPCM) menghasilkan Semen Padang dengan bahan baku pengolahan turbin yang berasal dari tambang batubara Sawahlunto (Zed, dkk 2001:48-50). Kehadiran tiga perusahaan di luar Ombilin Mijnen menurut Mestika Zed menjadi sebuah triumvirat yang menyangga perekonomian Sumatra Barat hingga kini.

Beroperasinya tambang batubara sejak masa Kolonial Belanda, telah mendorong proses multikultural di Sawahlunto. Erwiza dalam tulisannya menyebut, hadirnya batubara secara langsung, telah mendorong beragam etnis hadir di Sawahlunto Hadirnya etnis Jawa, Madura, Bugis di Sawahlunto, tidak lepas dari kebijakan pemerintah Kolonial Belanda, guna merekrut tenaga buruh tambang bawah tanah (Erman 2002). Tidak memadainya buruh kontrak yang didatangkan pada tahap awal, mendorong pemerintah Kolonial Belanda kembali mendatangkan tenaga tambahan, terutama dari penjara yang ada di Batavia. Proses multikultural itu secara tidak langsung terjadi melalui perkawinan antara buruh migran dengan penduduk lokal, sampai pembentukan bahasa khas Sawahlunto, yakni tansi.

Seabad lebih mengeksploitasi batubara, pasca tahun 2002 Sawahlunto mulai sepi dari aktivitas penambangan batubara. Pasar-pasar yang biasanya bergairah melayani kebutuhan warga kota dan karyawan tambang PT. Bukit Asam (Persero), Tbk -Unit Pertambangan Ombilin (PT.BA-UPO) sudah berangsur sepi. Perubahan mindset dari kota tambang menjadi kota tambang berbudaya, menjadi sebuah keharusan mengingat sumber Anggaran Pendapatan Belanja Daerah (APBD) dari Sawahlunto berasal dari pajak tambang PT.BA-UPO. Sampai tahun 2004, 
Pemerintah Kota Sawahlunto dan PT.BA-UPO menandatangani Surat Perjanjian Kerjasama, yang menandai awal beralihnya Sawahlunto menjadi kota tambang berbudaya. Sisi menarik dari tulisan ini adalah menganalisis upaya pemerintah Sawahlunto dalam mengembangkan potensi wisata melalui aspek multikultural.

Untuk mengurai tulisan ini lebih lanjut, ada beberapa item pertanyaan yang akan diajukan, yakni apa sebab-sebab Sawahlunto beralih menjadi kota tambang wisata berbudaya?, dan bagaimana pengembangan wisata Sawahlunto dari sisi analisis SWOT? Seluruh item pertanyaan di atas, akan terjawab dalam pembahasan berikutnya.

Adapun tujuan tulisan ini adalah, untuk mendeskripsikan kota Sawahlunto dari kota tambang beralih menjadi kota Tambang wisata budaya serta strategi pengembangan wisata Sawahlunto dari sisi analisis SWOT. Artinya tulisan ini sekaligus menguraikan penggunaan analisis SWOT dalam pengembangan Tambang wisata berbudaya.

Melihat sisi pengembangan wisata di Sawahlunto yang berbasis budaya, ada beberapa konsep yang akan ditawarkan dalam tulisan ini. Wisata merupakan kegiatan perjalanan yang dilakukan oleh seseorang atau sekelompok orang dengan mengunjungi tempat tertentu untuk tujuan rekreasi, pengembangan pribadi, atau mempelajari keunikan daya tank wisata yang dikunjungi, dalam jangka waktu sementara. Bila merujuk pada kata pariwisata berarti berbagai macam kegiatan wisata dan didukung berbagai fasilitas serta layanan yang disediakan oleh masyarakat, pengusaha, dan pemerintah (Undang-undang RI nomor 10 tahun 2009 tentang Kepariwisataan).

Berdasarkan defenisi di atas, melihat cluster model wisata yang bisa diterapkan adalah industri pariwisata tambang. Menurut Gamal Suwantoro dalam bukunya Dasar Dasar Pariwisata menyatakan bahwa Industri pariwisata adalah kumpulan usaha pariwisata yang saling terkait dalam rangka menghasilkan barang dan/atau jasa bagi pemenuhan kebutuhan wisatawan dalam penyelenggaraan pariwisata (Suwantoro 2001:5). Berkenaan dengan alternatif pengembangan wisata melalui pelestarian multikultural, ada beberapa konsep yang berhubungan dengan multikultural. Multikulturalisme merupakan pola pikir yang menuntut kesediaan untuk menerima kehadiran kelompok dan sistem nilai lain dalam kehidupan bersama tanpa memperdulikan perbedaan budaya, sratifikasi sosial, jender, dan agama (Muchtar 2004). Konsep ini sejalan dengan pandangan yang menyatakan multikulturalisme sebagai ideologi yang mengakui dan 
mengagungkan perbedaan dan kesederajatan manusia baik sebagai individu maupun sebagai anggota masyarakat sekaligus dengan kebudayaannya (Suparlan, 2002).

Selain itu ada yang menyebut multikulturalisme sebagai prinsip yang menghendaki semua kita menerima perbedaan, terbuka terhadap perubahan, menghendaki kesetaraan, mampu mengenali diri kita yang sesungguhnya dalam hubungan dengan "keasingan" orang lain; prinsip ini harus menjadi pijakan dalam mengambil setiap tindakan. Lebih lanjut Watson (dalam Ismaun, 2007:18) mengingatkan, bahwa dalam memahami makna multikulturalisme, budaya (culture) dipandang sebagai proses dinamis dari adaptasi manusia terhadap perjalanan sejarahnya yang merupakan kondisi untuk mempertahankan kehidupan melalui keterlibatan secara simpatik terhadap cara-cara baru dalam memahami dunia dan meresponnya.

Bila memang pemerintah Sawahlunto ingin mengembangkan potensi wisata tambang berbasis budaya, sewajarnya poin-poin utama dalam multikultural itu seharusnya, menjadi bagian penting dalam pengembangan wisata pada tahun berikutnya. Seluruh konsep tersebut, akan menjadi alat analisis untuk membedah persoalan pengembangan wisata berbasis multikultural di Sawahlunto.

\section{METODE PENELITIAN}

Penulisan artikel ini menggunakan metode penulisan deskriptif kualitatif dengan mengkombinasikannya dengan metode penulisan sejarah yaitu heuristik berupa mengumpulkan sumber tertulis dari Perpustakaan Daerah Propinsi Sumatera Barat, Perpustakaan dan Arsip Kota Sawahlunto, dan Perpustakaan BPNB Sumatera Barat. Data juga diperoleh melalui wawancara dengan tokoh masyarakat dan pejabat di Kota Sawahlunto. Selanjutnya data yang diperoleh dikritik lalu diinterpretasi hingga menghasilkan sebuah tulisan.

\section{PEMBAHASAN}

\section{Rendezvous Kota Tambang dan Multikultural}

Keputusan Belanda mencari batubara ke negeri jajahan pada abad ke-19 menjadi awal tumbuhnya pertambangan modern batubara di wilayah Indonesia (Furnivall 1948:235). Di Sumatera Westkust, kisahnya bermula pada 1858, ketika seorang ahli tambang, berkebangsaan Belanda bernama C. de Groet, memprediksi terdapat kandungan batubara di Ombilin 
Sawahlunto. Kemudian, ekplorasi berikutnya dilakukan de Grave, yang tidak akan membayangkan Sawahlunto tiba-tiba berubah menjadi kota kosmopolitan untuk ukuran zamannya. Di puncak kekuasaan kolonial pada paroh pertama abad ke-20, Sawahlunto juga adalah kota yang mewah dalam arti kurun tersebut: hampir setengah abad lamanya kota ini berlimpah kemewahan dan bermandikan cahaya di tengah pedalaman Sumatra yang kebanyakan masih berada dalam kondisi gelap-gulita.

Sejak resmi berproduksi tahun 1891, Ombilin Mijnen yang didirikan pemerintah Kolonial Belanda, mulai kesulitan dengan buruh tambang bawah tanah. Melalui Departemen Kehakiman, mereka mengerahkan narapidana asal penjara-penjara di Batavia, terutama dari penjara di Glodok dan di Cipinang yang sudah penuh sesak. Narapidana itu dipaksa menjadi buruh tambang batubara Ombilin, kuli pembangunan jalan kereta api, dan pada proyek-proyek pekerjaan umum lainnya. Ketika calon buruh dan kuli asal Batavia itu tiba di Sumatera Barat. Menurut Erwiza, dalam bukunya Membara Batu Bara. Konflik Kelas dan Etnik Ombilin Sawahlunto-Sumatera Barat 1892-1996, menjelaskan bahwa Residen menugaskan buruh yang berasal dari etnis Jawa, Bali, dan Bugis itu membantu pekerjaan umum dengan kontrak selama setahun (Erman 2005). Proses ini merupakan awal multikultural di Sawahlunto.

Pada fase berikutnya, pemerintah kembali mengerahkan 366 buruh paksa diarak untuk bekerja di tambang pertama, di desa Durian (Arnas-RI, Register 1891-1907:412-413). Rupanya pengerahan eks narapidana asal Batavia itu, belum memenuhi hasrat direktur tambang batubara Ombilin, untuk meningkatkan jumlah produksi Tambang Bawah Tanah. Tahun 1893, pemerintah kembali mengerahkan para napi yang dihukum lebih dari lima tahun. Pimpinan Ombilin Mijnen harus membayar kepada Departemen Kehakiman sebesar 27 sen per hari, untuk seorang buruh paksa. Pada masa itu, buruh paksa dibagi kedalam dua kategori, yaitu: tawanan politik dan kriminal biasa. Pada tahun 1915 direktur perusahaan menghentikan penerimaan buruh paksa dari Batavia, akibatnya pada tahun itu terjadi kekurangan tenaga buruh.

Proses multikultural berikutnya terjadi ketika buruh-buruh tambang tersebut, ada yang melaksanakan perkawinan dengan penduduk setempat. Mereka yang berasal dari etnis Jawa, Bali, dan Bugis itu ada yang menikah dengan orang Sawahlunto, Talawi, dan lain sebagainya. Perkawinan antara buruh tambang dengan penduduk lokal, telah melahirkan sebuah bahasa baru, yang dikenal dengan nama Tansi. Bahasa Tansi adalah bahasa yang berasal dari buruh 
tambang batubara di masa kolonial di Sawahlunto. Para buruh inilah yang menciptakan model bahasa kreol sejak kawasan ini menjadi kota tambang modern sekira seabad silam. Bahasa tansi awalnya merupakan bahasa pijin karena bahasa ini bersifat poligenetik, yakni campuran dari beberapa bahasa buruh tambang dari lain-lain etnis, seperti Minangkabau, Jawa, Cina, Madura, Sunda, Bugis, Bali, dan Batak, dengan bahasa dasar Melayu dan ditambah dengan bahasa Belanda. Percampuran itu ditandai dengan munculnya sapaan-sapaan seperti $n i$, uni, kang, beli, deyeng, daeng, incek, ndok, neng, dan seterusnya. ${ }^{1}$ Proses dekreolisasi ini disebabkan oleh pendidikan, pergaulan, perkembangan teknologi informasi, pendatang, mobilitas sosial masyarakat Sawahlunto yang melanjutkan tingkat pendidikan ke Padang maupun Jawa. Dekreolisasi itu juga, kata Elsa, telah menempatkan bahasa Tansi sebagai bahasa kedua setelah bahasa Indonesia (Elsa Putri Ermiah Syafril dalam https://radiobuku.com/2010/11/bahasa-tansisawahlunto-sebagai-bahasa-kreol/ diunduh tanggal 1 Januari 2018).

Mengenai gaya hidup pekerja, terutama untuk kalangan menengah atas, Susan Rodgers menyebutnya sebagai standar jetset. Rodgers menulis tentang keberadaan kolam-kolam pemandian, mobil-mobil pribadi yang mahal milik para orang kaya menyesaki jalan-jalan kota yang lapang dan mulus (Asnan 2002:729), juga rumah-rumah bola (Socialiteit) tempat orangorang Belanda menghibur diri pada akhir pekan berdansa, bermain bolling dan bilyar (Rodgers 2009: 99,104). Kemewahan hidup yang sempat berhenti sesaat ketika Jepang datang hingga dekade 1970-an, tetapi berlanjut kembali hingga lebih dua setengah dekade setelah itu.

Padahal, kota itu dulunya hanya sehamparan persawahan dan perladangan di tengah cekungan sempit perbukitan yang dialiri Sungai Lunto. Kawasan yang sama sekali tidak penting bagi penduduk pribumi dan bahkan diabaikan oleh mata seorang birokrat kolonial sekalipun. Erwiza Erman dalam bukunya Lorong lorong Kelam Perantaian menulis, "Daerah pinggiran yang dikelilingi hutan belantara, nyaris tidak berpenghuni ..., bagi penduduk sekitar seperti Silungkang dan Kubang, hanyalah sebagai areal persawahan, berkebun, dan berladang," (Erman, dkk 2010:18-19). Kemudian Carin van Empel dalam Vincent J.H Houben, J. Thomas Linblad menyatakan bahwa kawasan yang hanya disebut sebagai 'kampung kecil' pada sebuah lembah sempit yang terpisahkan dari negeri-negeri di sekelilingnya oleh tebing perbukitan yang terjal

\footnotetext{
${ }^{1}$ Elsa Putri Ermiah Syafril membagi dialek bahasa Tansi menjadi dua: mereka yang tinggal di Pusat Kota Lama (Kecamatan Lembah Segar) dan Teras Kota Lama (Kecamatan Barangin dan Talawi). Dialek PKLm sudah dipengaruhi sedemikian rupa oleh bahasa Indonesia, sementara yang masih asli bahasa Tansi adalah penutur di TKLm. Lebih lanjut baca "Bahasa Tandi Sawahlunto Sebagai Bahasa Kreol
} 
(Empel 1999:179).

Kemewahan Sawahlunto yang pernah dirasakan oleh masyarakat masih berlanjut sampai Indonesia merdeka, meskipun nanti berakhir seiring redupnya produksi batubara pada tahun 2002. Maraknya Penambang Tanpa Izin (PETI) yang memasuki kawasan tambang terbuka PT.BA-UPO, telah membawa perusahaan tambang tertua di Sumatra itu berkurang drastis produksinya dan terus-menerus menderita kerugian. ${ }^{2}$

Sejak itu Sawahlunto berubah menjadi kota yang tidak punya harapan, daerah ini seolaholah sudah memasuki masa akhir, tidak berdaya untuk melanjutkan masa depannya. Kondisi itu menghantui pikiran masyarakat, apa yang bisa mereka lakukan dengan berakhirnya masa jaya batubara? Pertanyaan itu kemudian dijawab oleh Walikota Amran Nur, bahwa Sawahlunto mampu hidup dan berkembang tanpa batubara. Lebih lanjut Amran menawarkan industri pariwisata berbasi tambang, yang dmulai dari pengembangan Museum Kereta Api dan memakai aset milik PTBA-UPO, salah satunya Goedang Ransoem. Usaha walikota Sawahlunto itu, membuat Sawahlunto kembali menggeliat, dan kehidupan ekonomi kembali bergairah. Pada hal apa yang yang dilakukan Amran Nur, belum sepenuhnya mengembangkan potensi yang dimiliki Sawahlunto.

\section{Pengembangan Potensi Sumberdaya Wisata non Tambang}

Bila dilihat dalam paket-paket wisata yang sudah ada di Indonesia, ada dua hal yang harus digarisbawahi. Persoalan yang dimaksud ada pada paket dan harga produk. Sebagaimana diketahui, bahwa paket setidaknya berisi dua produk (layanan, dan / atau aktivitas pariwisata) dengan harga tunggal yang dapat ditawarkan dalam jangka waktu tertentu. Sedangkan, untuk harga produk yang dibundel, jika dipecah secara terpisah, seharusnya tidak sama dengan harga paket (Asnawi Bahar : Dalam Diskusi Nasional Pariwisata di sawahlunto, tanggal 30 November 2017). Artinya, untuk mengangkat Sawahlunto sebagai paket wisata seharusnya sudah ada branding. Branding Sawahlunto itu terletak pada kota herritage dan multikulturalism

\footnotetext{
${ }^{2}$ Sempat steril dari PETI tiga bulan lebih, pada awal Januari 1999 mereka kembali berulah di Kuasa Penambangangan (KP) PT.BA-UPO. Pada awal tahun 1999 tercatat 2000 penambang ilegal sudah mengerahkan alat berat di Barrier Pillar dan KP tambang terbuka PT.BA-UPO. Akibat ulah PETI, PT.BA-UPO kembali menderita kerugian. Untuk Barrier Pillar, tim UPO sudah beberapa kali menutup lubang di Langkok, Sawah Rasau IV, Air Karuh, Medan Bapaneh, Durian dan Karang Anyar, namun tetap dibuka PETI. Lebih lanjut baca Semangat, 18 Januari 1999.
} 
masyarakatnya.

Untuk mensinergikan branding tersebut, diperlukan kerjasama, terutama bagaimana memberdayakan masyarakat Sawahlunto sebagai penggerak dari pariwisata, dan bukan sebagai penonton saja. Cara pandang seperti ini perlu dikembangkan, karena masyarakat harus terlibat dalam setiap pengambilan putusan, terutama yang berhubungan dengan potensi dan pengembangan wisata. Artinya, partisipasi masyarakat sejak awal harus dilibatkan, karena hal itu akan lebih menjamin kesesuaian pelaksanaan program pengembangan potensi yang berhubungan dengan menunjang usaha wisata.

Keterlibatan masyarakat dalam pelestarian warisan budaya diperkuat oleh Undangundang no. 11 tahun 2010 tentang Cagar Budaya, yang berarti menjadi sebuah keharusan dan diharapkan sebagai energi baru dalam pelestarian warisan budaya, yang selama ini didominasi pemerintah. Hal ini menjadi tantangan bagi penggiat pelestarian warisan budaya, maupun pemerintah untuk memperjelas aturannya (Undri dkk, 2015).

Aturan ini juga terdapat dalam Undang-Undang Nomor 9 tentang Kepariwisataan yang menjelaskan bahwa daya tarik wisata terdiri dari: ciptaan Tuhan YME, yang berwujud keadaan alam flora, fauna serta hasil karya manusia yang berujud museum, peninggalan sejarah, seni budaya, wisata agro wisata tirta, wisata buru, wisata petualangan alam, taman rekreasi dan tempat hiburan.

Sawahlunto memang memiliki potensi yang luar biasa di sektor industri pariwisata. Kota ini memiliki semua potensi yang berhubungan dengan peninggalan warisan budaya benda seperti bangunan tua, makam, arca, dan lain sebagainya. Begitu pula dengan peninggalan warisan budaya tak benda yang berhubungan dengan praktek, representasi, ekspresi, pengetahuan, keterampilan, serta alat-alat, artefak dan ruang-ruang budaya terkait dengan yang diakui oleh berbagai komunitas, kelompok dan dalam hal tertentu perseorangan sebagai warisan bagian dari warisan budaya mereka.

Warisan budaya takbenda yang diwariskan dari generasi ke generasi, senantiasa diciptakan kembali oleh berbagai komunitas dan kelompok sebagai tanggapan mereka terhadap lingkungannya, interaksinya dengan alam serta sejarahnya dan memberikan merasa jati diri dan dan berkelanjutan. Warisan budaya tak benda meliputi: tradisi dan ekspresi lisan, termasuk 
bahasa sebagai wahana budaya tak benda, seni pertunukan, adat istiadat masyarakat,dan perayaaperayaan, pengetahuan dan kebiasaan perilaku mengenai alam dan semesta dan kerajinan tradisional, budaya tak benda ini dikenal juga dengan istilah budaya hidup (Hariadi dkk 2014).

Sekarang, tinggal bagaimana pihak-pihak terkait dalam mengembangkan potensi tersebut. Guna mengembangkan potensi wisata yang sudah ada, tentu harus memiliki konsep, sehingga jelas kemana arah pengembangannya. Hanya saja untuk pengembangan wisata tidak sekedar mempersiapkan konsep, tetapi yang sangat penting adalah perencanaan yang sangat matang, serta manajemen pengelolaan yang baik.

Sehubungan dengan pokok persoalan yang berkaitan dengan pengembangan pariwisata dengan memanfaatkan semua potensi yang ada, perlu melakukan banyak persiapan diantaranya seperti yang akan dibahas berikut ini.

1. Pengembangan Prasarana dan Sarana Pariwisata

Guna meningkatkan pembangunan pariwisata dengan mengembangkan potensi yang ada tidak bisa lepas dari pengembangan masyarakat lokal yang menjadi bagian dari potensi itu, menurut Nuryanti, dalam tulisannya Perencanaan Pembangunan Pariwisata Berkelanjutan dan Berwawasan Lingkungan menulis:

a. Memajukan tingkat hidup masyarakat sekaligus melestarikan identitas budaya dan tradisi lokal

b. Meningkatkan pendapatan secara ekonomis dan mendistribusikan secara merata pada penduduk lokal

c. Berorientasi pada pengembangan wirausaha berskala kecil dan menengah dengan daya serap tenaga kerja besar dan berientasi pada teknologi tepat guna.

d. Mengembangkan semangat kompetitif sekaligus kooperatif

e. Memanfaatkan pariwisata seoptimal mungkin sebagai agen perubahan sosial, budaya dan lingkungan kearah perubahan yang positif dengan meminimalisasikan dampak negatif (Wiendu Nuryanti : Makalah Dalam Pendidikan dan Pelatihan mengenai Dampak Lingkungan. UGM. 4-21 Agustus 1997). 


\section{Model Pengembangan Pariwisata Sawahlunto Menurut Analisis SWOT}

Adapun pengembangan pariwisata dengan memanfaatkan potensi sumberdaya wisata yang ada, serta didukung minat dari pihak-pihak terkait untuk pengembangannya, perlu terlebih dahulu melakukan analisis SWOT (Strenght, Weakness, Opportunity and Threat) guna mengkaji kemungkinan-kemungkinan pengembangan wisata ke depan. Analisis ini merupakan salah satu teknik untuk melakukan identifikasi yang berkaitan dengan hal-hal yang meliputi: kekuatan, kelemahan, peluang dan ancaman yang harus dikaji untuk dijadikan dasar pengembangan atau penyelesaian suatu persolan dimasa depan. Jadi dengan analisa SWOT ini, diharapkan agar pengembangan pariwisata di kota Sawahlunto dapat tercapai dengan perencanaan yang lebih jelas tujuannya.

Terkait dengan hal itu, penulis mencoba melakukannya secara sederhana dengan menggunakan analisa SWOT terhadap Kota Sawahlunto, dalam rangka melihat kemungkinankemungkinan pengembangan wisata kedepan:

\section{a. Kekuatan}

Kekuatan-kekuatan yang dimiliki Sawahlunto dalam pengembangan wisata, bisa dilihat dari berbagai aspek, mulai dari potensi sumber budaya, peninggalan bersejarah, potensi kekayaan alam, hingga dalam bentuk kerajinan yang dihasilkan masyarakat itu sendiri.

1. Potensi sumber budaya, baik berbentuk benda maupun non benda. Budaya berbentuk benda seperti alat-alat musik tradisional (talempong dan gendang) dan non benda seperti adat istiadat, upacara adat, seni tari, makanan dan lain-lain.

2. Potensi sumberdaya berbentuk peninggalan sejarah mulai dari peninggalan prasejarah, klasik, Islam (mesjid Nurul Huda, Mesjid Agung Nurul Islam, Kolonial (Gudang Ransum, Rumah dokter, rumah jaksa, Stasiun Kereta Api, Lubang Terowongan Saringan, Rumah sakit, Gereja, dan lain sebagainya.

3. Potensi alam, contohnya keindahan bukit barisan yang mengelilngi kota Sawahlunto.

4. Berbagai potensi hasil kerajinan rakyat, guna menunang pariwisata Kota sawahlunto Seperti tenun, kerajinan asbak batu bara,

5. Dukungan pemerintah terhadap pengembangan wisata Kota Sawahlunto. 


\section{b. Kelemahan}

Kelemahan-kelemahan yang mesti dibenahi untuk Kota Sawahlunto, terutama dalam pengembengan wisata, ada beberapa catatan penting yang mesti disimak.

a. Prasarana pariwisata masih kurang.

b. Sarana parawisata seperti tempat bermain, transportasi regular, penginapan, rumah makan, telokmunikasi masih kurang.

c. Objek-objek wisata yang ada, baik sejarah, budaya dan alam belum ditata secara maksimal.

d. Berbagai potensi budaya yang dimiliki belum dipaket untuk atraksi wisata.

e. Berbagai kerajinan rakyat belum dikembangkan secara maksimal.

f. Kurang investasi dalam pengembangan pariwisata.

c. Peluang

Dari kekuatan dan kelemahan tersebut, sebenarnya Sawahlunto memiliki peluang besar dalam mengelola destinasi wisatanya sendiri, sehingga wisatawan yang hadir tidak saja mancanegara, namun juga internasional.

1. Kota sawahlunto mempunyai potensi untuk menjadi daerah tujuan wisata (DTW)

2. Kalau dikelola dengan baik memunyai potensi sebagai sumber pendapatan Asli Daerah Kota sawahlunto

3. Kalau masyarakat disiapkan, maka akan membuka lapangan kerja dan dunia usaha

4. Meningkatkan pendapatan dan kesejahteraan masyarakat

5. Adanya pariwisata di sawahlunto, akan memicu terjadinya aktivitas pelestarian kebudayaan agar dapat menambah daya tarik wisata.

6. Terbukanya kesempatan bagi masyarakat untuk berpartisifasi sebagai pelaku utama pariwisata.

\section{d. Ancaman}

Selain potensi kekuatan, kelemahan, dan peluang yang dimiliki Sawahlunto, ada satu faktor yang tidak boleh diabaikan, yakni ancaman. Sebagaimana diketahui bahwa ancaman yang bisa saja memperburuk citra Sawahlunto dimata wisatawan, umumnya terjadi di tingkat lokal. 
1. Pengaruh budaya asing ditakutkan memberi pengaruh negatif terhadap kehidupan sosial budaya masyarakat kota Sawahlunto.

2. Menumbuhkan pengaruh negatif terhadap tatanan adat masyarakat.

3. Terjadinya berbagai kerusakan terhadap lingkungan akibat aktivitas wisata.

Berdasarkan hasil analisis SWOT di atas, Kota sawahlunto memiliki peluang besar guna membangun dan mengembangkan daerahnya sebagai destinasi wisata. Selain itu, dapat pula disusun visi dan misi pengembangan pariwisata kota Sawahlunto berdasarkan analisis SWOT tersebut. Visi merupakan tujuan yang hendak dicapai, sedangkan misi merupakan langkahlangkah atau upaya yang dilakukan guna mencapai visi. Lebih jelasnya maka berikut ini akan diuraikan perkiraan visi dan misi pariwisata kota Sawahlunto yang dijadikan acuan yaitu:

\section{VISI}

Pengembangan Pariwisata budaya, sejarah dan alam dengan melibatkan partisipasi masyarakat sebagai pelaku utama.

\section{MISI}

1. Penataan semua sarana dan prasarana dilingkungan objek wisata yang ada di seluruh kota sawahlunto

2. Penataan semua sarana prasarana penunjang bagi daerah tujuan pariwisata

3. Menyiapkan berbagai paket wisata budaya, sejarah dan alam guna mendukung atraksi wisata.

4. Menyiapkan berbagai strategi promosi pariwisata

5. Menyiapkan dan mengembangkan peran serta masyarakat

6. Menyiapkan dan mengembangkan manajemen pengelolaan pariwisata.

Meskipun dari analisis SWOT Kota Sawahlunto memiliki potensi besar dalam pengembangan pariwisata, namun harus tetap memperhatikan aspek-aspek yang membahayakan terhadap kehidupan masyarakat, maupun lingkungan dari objek wisata itu sendiri. Oleh sebab 
itu perlu ada langkah-langkah antisipasi pada masyarakat Kota sawahlunto agar dampak yang merugikan masyarakat dan lingkungan tersebut bisa diminimalkan. Mengingat faktor-faktor yang telah dijelaskan di atas, beberapa langkah berikut perlu dilakukan:

1. Perlu melibatkan pemuka masyarakat dalam mengawasi dan membina langsung kepada anak kemenakannya agar tetap konsisten dan patuh dalam menjalankan nilai-nilai sosial dan adat yang berlaku di Sawahlunto.

2. Perlu melibatkan alim ulama, pendeta dan lainnya dalam melakukan pembinaan mental,etika, dan akhlak sesuai dengan aturan agama.

3. Perlu adanya kerjasama lintas sektoral dalam struktur dalam struktur pemerintahan dalam melakukan pengawasan dan pembinaan terhadap semua pihak pelaku pariwisata di kota Sawahlunto.

Agar apa yang dimaksud dalam analisa SWOT di atas dapat diatikulasikan dengan mudah, untuk itu diagram dibawah ini akan membantu untuk mempermudah kesimpulan dari hasil analisa.

\section{Kekuatan}

1. Potensi Sumber Budaya, baik berbentuk benda maupun non benda. Budaya berbentuk benda seperti alatalat musik tradisional ( talempong, gendang) dan non benda seperti adat istiadat, upacara adat, seni tari, makanan dan lain-lain

2. Potensi sumberdaya berbentuk penggalan sejarah mulai dari peninggalan prasejarah, Klasik, Islam (mesjid Nurul Huda, Mesjid Agung Nurul Islam, Kolonial (Gudang Ransum, Rumah dokter, rumah jaksa, Stasiun Kereta Api, Lubang Terowongan Saringan, Rumah sakit, Gereja dll.

\section{Kelemahan}

a. Prasarana pariwisata masih kurang

b. Sarana parawisata seperti tempat bermain, transportasi regular, penginapan, rumah makan, telokmunikasi masih kurang

c. Objek-objek wisata yang ada, baik sejarah, budaya dan alam belum ditata secara maksimal..

d. Berbagai potensi budaya yang dimiliki belum dipaket untuk atraksi wisata.

e. Berbagai kerajinan rakyat belum dikembangkan secara maksimal

f. Kurang investasi dalam pengembangan pariwisata. 

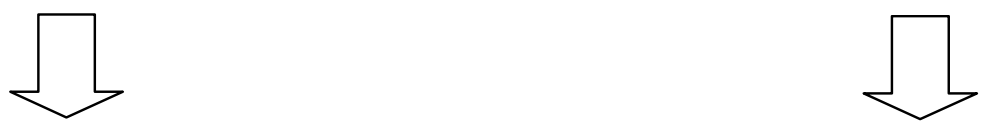

\section{VISI}

Pengembangan Pariwisata budaya, sejarah dan alam dengan melibatkan partisipasi masyarakat sebagai pelaku utama.

\section{MISI}

1. Penataan semua sarana dan prasarana dilingkungan objek wisata yang ada di seluruh kota sawahlunto

2. Penataan semua sarana prasarana penunjang bagi daerah tujuan pariwisata

3. Menyiapkan berbagai paket wisata budaya, sejarah dan alam guna mendukung atraksi wisata.

4. Menyiapkan berbagai strategi promosi pariwisata

5. Menyiapkan dan mengembangkan peran serta masyarakat

6. Menyiapkan dan mengembangkan manajemen pengelolaan pariwisata.

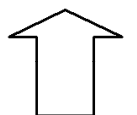

\section{Peluang}

a. Kota Sawahlunto mempunyai potensi untuk menjadi daerah tujuan wisata (DTW)

b. Kalau dikelola dengan baik mempunyai potensi sebagai sumber pendapatan Asli Daerah Kota sawahlunto

c. Kalau masyarakat disiapkan, maka akan membuka lapangan kerja dan dunia usaha

d. Meningkatkan pendapatan dan kesejahteraan masyarakat

e. Adanya pariwisata di Sawahlunto, akan memicu terjadinya aktivitas pelestarian kebudayaan agar dapat menambah daya tarik wisata.

f. Terbukanya kesempatan bagi masyarakat untuk berpartisifasi sebagai pelaku utama pariwisata.

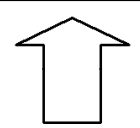

\section{Ancaman}

a. Pengaruh budaya asing ditakutkan member pengaruh negatif terhadap kehidupan sosial budaya masyarakat kota Sawahlunto.

b. Menumbuhkan pengaruh negatif terhadap tatanan adat masyarakat.

c. Terjadinya berbagai kerusakan terhadap lingkungan akibat aktivitas wisata. 


\section{PENUTUP}

Masyarakat Sawahlunto yang multikultural terlihat dari komposisi etnisitasnya yang berasal dari Minangkabau, Jawa, Batak, dan Cina, telah menjadikan Sawahlunto memiliki ciri khas dan unik, bila dibandingkan dengan daerah-daerah lainnya di Sumatera Barat.

Branding wisata yang melekat dalam diri Sawahlunto bisa dilihat dari kota tua herritage sebagai warisan kolonial Belanda, bahasa tansi sebagai wujud multikultural, sampai kepada tingkat industri rumah tangga yang dilakoni masyarakat, menjadi potensi yang besar untuk mengembangkan wilayah ini sebagai daerah khusus untuk wisata tambang berbudaya.

Berkenaan dengan potensi wisata Sawahlunto, perlu kiranya perhatian dan penanganan serius dari semua pihak. Pemerintah Kota Sawahlunto sebaiknya mempersiapkan berbagai sarana prasarana penunjang untuk seluruh daerah-daerah wisata. Sarana dan prasarana yang dimaksud berupa: jalan, sarana transportasi, saluran komunikasi, restoran, dan penginapan. Masyarakat daerah sekitar objek wisata seharusnya siap untuk menghadapi pengaruh negatif yang mungkin menyertai setiap kunjungan wisata ke daerah mereka.

\section{DAFTAR PUSTAKA}

\section{Arsip}

Arnas-RI,Register 1891-1907.

Undang-undang RI nomor 10 tahun 2009 tentang Kepariwisataan.

\section{Surat Kabar}

Semangat, 18 Januari 1999.

\section{Jurnal}

Al-Muchtar, Suwarna. 2004. "Multikulturalisme dan Pendidikan Multikultural dalam Era Otonomi Daerah.” Mimbar Pendidikan. Jurnal Pendidikan UPI Th. XXIII No.4.

Asnan, Gusti. 2002. "Transportation on the west coast of Sumatra in the nineteenth century" Bijdragen tot de Taal-, Land- en Volkenkunde, edisi 158.

Erman, Erwiza. 2002. Hidden Histories: Gender, Family, and Community In The Ombilin Coalmines (1892-1965) Clara Working Paper No.13.

Rodgers, Susan. 2005. “A Nederlander woman's recollections of colonial and wartime Sumatra: from Sawahlunto to Bangkinang internment camp", Indonesia, 79. 
Suparlan, Parsudi. 2002."Menuju Masyarakat Indonesia yang Multikutural”, . Jurnal Antropogi Indonesia, tahun XXVI, No.69. Terbitan UI dan Yayasan Obor. Indonesia.

\section{Buku}

Erman, Erwiza. 2005. Membaranya Batu Bara. Konflik Kelas dan Etnik Ombilin SawahluntoSumatera Barat 1892-1996. Jakarta : Desantara, 2005.

, Erwiza dkk. 2010. Lorong-lorong Kelam Perantaian. Jakarta: Verbum Publishing.

Furnivall, J.S. 1948.Netherlands Indies: A Study of Plural Economy. London: Cambridge University Press.

Houben, Vincent J. H and J. Thomas Linblad, dkk. 1999. Coolie Labour in Colonial Indonesia. A Studi of Labour Relations in the Outer Islands, c. 1900-1940. Wiesbaden: Harrassowitz.

Ismaun, 2007. Membangun Jati Diri Bangsa. Jakarta: Kompas.

Suwantoro, Gamal. 2001. Dasar-Dasar Pariwisata. Yogyakarta: Andi.

Undri dkk. 2015. Sejarah budaya Tambang kota Sawahlunto.Laporan kegiatan. Padang BPNB.

Verslag der Exploitatie van den Staatsspoorweg ter Sumatra's Westkust en van de Ombilinkolenvelden over 1893. Batavia : Landsdrukkerij, 1894-1930.

Zed, Mestika, Hasril Chaniago, dan Khairul Jasmi. 2001. Indarung: Tonggak Sejarah Industri Semen Indonesia Jakarta: Sinar Harapan.

\section{Skripsi, Tesis, Disertasi}

Abrar,"Angkutan Kereta Api dan Perkembangan Ekonomi Sumatera Barat 1887-1940",Tesis, Program Pascasarjana Universitas Indonesia, 2001.

\section{Website}

"Bahasa Tandi Sawahlunto Sebagai Bahasa Kreol dalam https://radiobuku.com/2010/11/ bahasa-tansi-sawahlunto-sebagai-bahasa-kreol/. Diunduh tanggal 1 Januari 2018.

\section{Presentasi Seminar}

Bahar, Asnawi. 2017. "Strategi Packaging Pariwisata", Power Point. Disampaikan dalam Diskusi Nasional Pariwisata di Sawahlunto tanggal 30 November 2017.

Nuryanti, Wiendu. 1997.Perencanaan Pembangunan Pariwisata Berkelanjutan dan Berwawasan Lingkungan, Makalah dalam Pendidikan dan pelatihan mengenai Dampak Lingkungan, kerja sama antara Depapostel dan Puspar UGM, Yogyakarta: 4-21 Agustus 1997. 